\title{
WET WATERBIRDS - A PROBLEM AT SEWAGE LAGOONS
}

\author{
by Robert W. Nero \\ Photographs by Roberi R. Taylor \\ Manitoba Museum of Man and Nature, Winnipeg
}

Bird watchers across the continent are becoming increasingly aware that sewage lagoons attract large numbers of birds. Indeed, several groups now regularly list an "aroma route" on their birding schedules. The sewage lagoons at Regina, Saskatchewan, which are two artificial bodies of water of about 120 and 130 acres each, have proven a boon to local birders. In late summer, when there seems to be considerable food available, surprising numbers of birds may congregate. On August 16,1964, for example, we saw an estimated 2000 Shovelers and 5000 Franklin's Gulls busily feeding in the lagoons. The Regina lagoons attract fewer birds in the spring when there is probably little food and when the effluent is more concentrated. To exhausted, night-flying spring migrants, the lagoons must seem a welcome haven. However, these waters may be potentially dangerous. In the spring of 1963 we found at least 24 Horned Grebes suffering from "wetfeathering" or loss of waterproofing, a peculiar condition evidently resulting from their immersion in the lagoon water (R. W. Nero. 1964. Detergents - deadly hazard to water birds. Audubon, 66:26-27). Loss of waterproofing is a dangerous condition, for wet waterbirds are easily chilled and they may succumb to cold water and wind. Furthermore, in their efforts to stay out of water, they become exposed to land predators.

Further observations of loss of waterproofing in grebes and other waterbirds were made at the Regina lagoons in the spring of 1964 . Our first

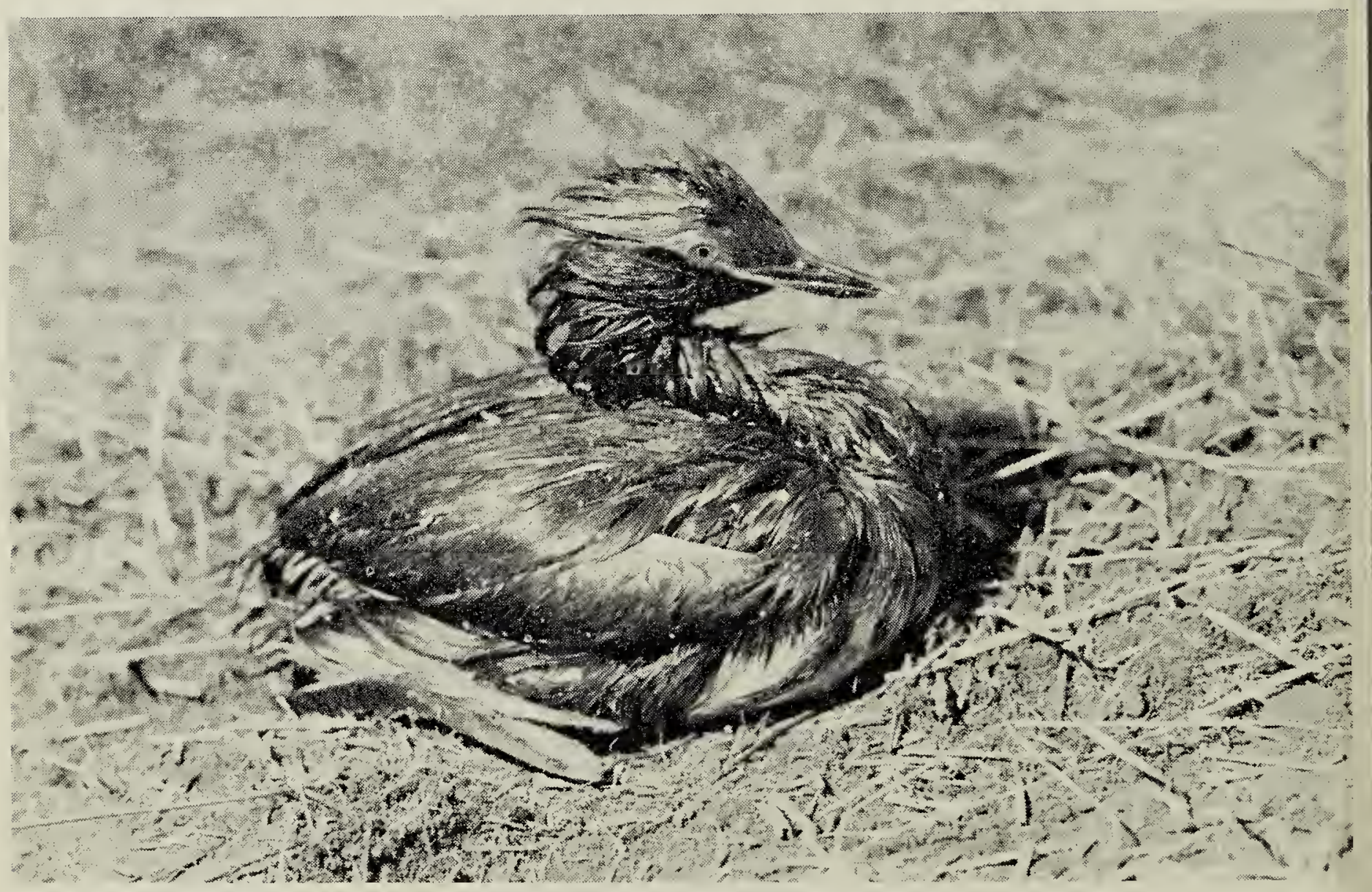

Thoroughly wet Horned Grebe sitting on the roadway, Regina sewage lagoon. 
record was a wet Horned Grebe found on April 25. More startling was a mixed flock of 19 wet grebes found late in the evening of May 8. The flock consisted of 17 Western Grebes, one Horned Grebe, and one Eared Grebe. These birds were sprawled out on a grassy slope on the edge of one of the two lagoons, the Western Grebes, especially, making an unusual and dramatic picture of stranded birds. They had evidently arrived during the previous night (we had checked the area daily), hence had been in the lagoon less than 24 hours. (Four other Western Grebes were seen on the same ponds, and 13 others on nearby Wascana Lake, all having evidently arrived on the same night.) Their wet appearance, and busy preening, gave ample evidence of the wet feather condition. Far from content to rest after a presumably long migration flight, they were busy removing the water from their soaked plumage. They did this with stropping motions of their long bills, drawing the feathers of their belly and flanks, strip by strip, through the bill, thus squeezing out the excess water. When we approached them, the Western Grebes lurched to their feet and scrambled down the slope and into the water. They sailed out from shore, ruffling their feathers, and reared up to spread and shake their wings. They were clearly uneasy in the water and soon returned and shuffled out on to land again, in spite of the presence of our car parked less than 15 feet from the edge of the water. The sloped bank which they were using was, however, the most accessible place to leave the water.

The Eared Grebe appeared to be in the worst condition-wet and tired, it refused to enter the water; the Horned Grebe followed the Westerns into the water, but it clambered back out again almost at once. The big Westerns appeared to be wet mainly on the belly and flanks, but they too seemed anxious to get back on to land, even fighting their way past a few aggressive individuals in the flock that screeched and jabbed at them as they attempted to get by. I was surprised to see this much aggression, for Western Grebes usually seem fairly tolerant. Here, however, forced together on the sloped bank, they were in closer quarters than is probably ever the case under normal conditions.

Some 36 hours later, on the morning of May 10, we returned and found 14 of the Western Grebes, and the Horned and Eared Grebes, resting on shore in the same place, still as "wettable" as ever. Their sorry condition gave us an opportunity to study and to photograph them at close range. When we approached they rushed to the safety of the water, but again soon returned to land, even though the car was parked within five feet!

Once more we were struck by the apparent urgency with which they stropped the water out of their feathers as soon as they were out on land; a kind of desperate preening of their wet feathers was an almost constant activity. Though they were as handsome as ever, strikingly so in the bright light of morning and particularly against the green grass, their obvious plight gave them the appearance of trapped animals. In effect, they were trapped on land-a dangerous situation for waterbirds. Only a few yards away we found one dead Western Grebe which had been shot, evidently with a .22 rifle.

In mid-afternoon we returned and arranged to capture the grebes, using a piece of wire netting to fence them off from the pond. After setting this in position we withdrew to allow the grebes to return to land.

It was a perfectly calm day, bright and warm, and by the time that we had set the netting in position the grebes had scattered hundreds of yards away to the far corners of the lagoon. However, 10 of the 14 Westerns soon returned to the same familiar slope, walking over the wire netting without any apparent concern. The other four Western Grebes, which we presumed to be the more aggressive members of the flock, and perhaps the stronger ones, suddenly, and much to our amazement, took flight over the 
Disturbed grebes ignore photographer.

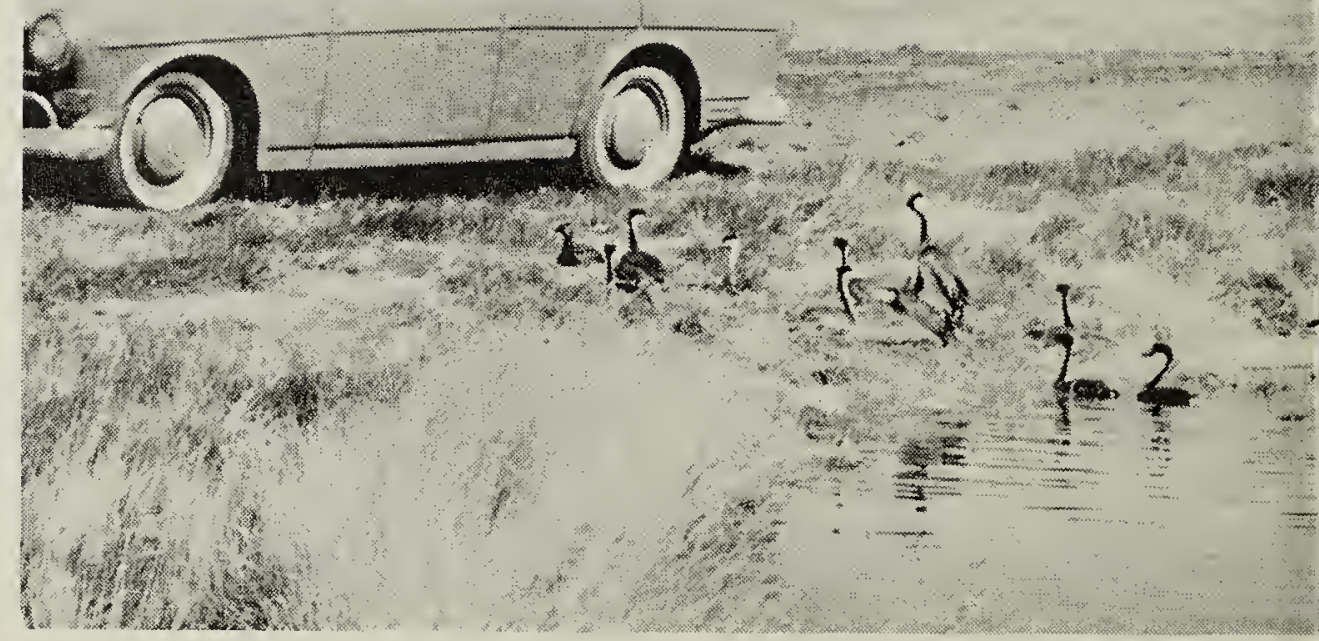

Grebes

of three species preening in the su 
lagoon! They had risen rapidly, circled the lagoon once while continuing to rise, then had headed straight east at a considerable height until out of sight; a most intriguing spectacle since one seldom sees grebes in flight.

This was perhaps our most significant observation of the season. Now we knew that even a fairly wet grebe could take flight and thus could leave the lagoon. Even after reaching clean, fresh water they would still be "wettable", would still want to get out onto land, and would thus be unusually vulnerable to predation. We also reasoned that if a wet grebe could take flight, then surely ducks, with a larger ratio of wing surface to body weight, could leave these lagoons with little effort. This left us wondering about the number of waterbirds which may suffer wetting on these lagoons but which simply fly away.

The 10 remaining Western Grebes were captured, measured, banded, and released into a natural marsh within the city limits - the Regina Waterfowl Park. One was found dead six days later on land in the Waterfowl Park; the eventual disappearance of Western Grebes from the Park suggests that the rest regained their powers of flight. One adult male, which we had released on May 9, survived to be found (by B. Daily, 903 Moose Jaw St., Penticton, B.C.) a year later in July 1965 at Whitehead Lake, British Columbia.

From May 11 to June 25 we observed or captured an additional 20 wet waterbirds, comprised of 5 Western Grebes, 3 Eared Grebes, 6 Pied-billed Grebes, 5 Ruddy Ducks, and 1 American Coot.

Waterbirds are notably waterproof, their short, dense and carefully arranged feathers being an effective means of repelling water. The layer of air trapped within their feathers aids them in maintaining buoyancy and also keeps them warm and dry, in or out of water, even in the coldest weather. In an article appropriately entitled "Why does a duck float?" (W.
D. Schmid. 1963. The Flicker (now The Loon), 35:117-121), the author concludes that waterproofness of feathers is "entirely structural" and that the "secretion of the preen gland is important to the maintenance of the water repellent nature of the feathers by preserving their physical structure and does not seem to function as a waterproof coating." Birds with plumage fouled with waste oil may be saved by washing their feathers with a detergent, but this treatment also affects the waterproofing. Such birds become wet-feathered when placed in water, and a considerable period of time may elapse before the waterproof condition is restored (Katherine Tottenham. 1963. Bird doctor. Country Book Club, London). Horned Grebes kept in captivity by us took up to two weeks to regain their waterproofing (Nero, op. cit.).

Our observations indicate that, whatever the cause, the waterproofing effect of feathers may be lost after only short contact with sewage waters. Admittedly, the chemical agents causing this effect are not known. On some of the days on which we found wet grebes the water in the lagoons appeared relatively clear, though on windy days a foam was always present. This, plus the enormous quantity of foam on the adjacent waters of Wascana Creek, into which water from the lagoons is discharged, led us to attribute the wetting effect to waste detergents, which are notable foam-causing agents. Detergent companies disagree, and there has been much concern expressed about conclusions in this respect.

In view of the increasing number of sewage lagoons and the attractiveness of some as breeding grounds for waterfowl (e.g. see: J. N. Dornbush and J. R. Anderson. 1964. Ducks on the wastewater pond. Water and sewage works, 3:271-276), the nature of the effect of waste synthetic detergents and other surface tension reducing pollutants upon the waterproofing mechanism of waterbirds deserves detailed study. 


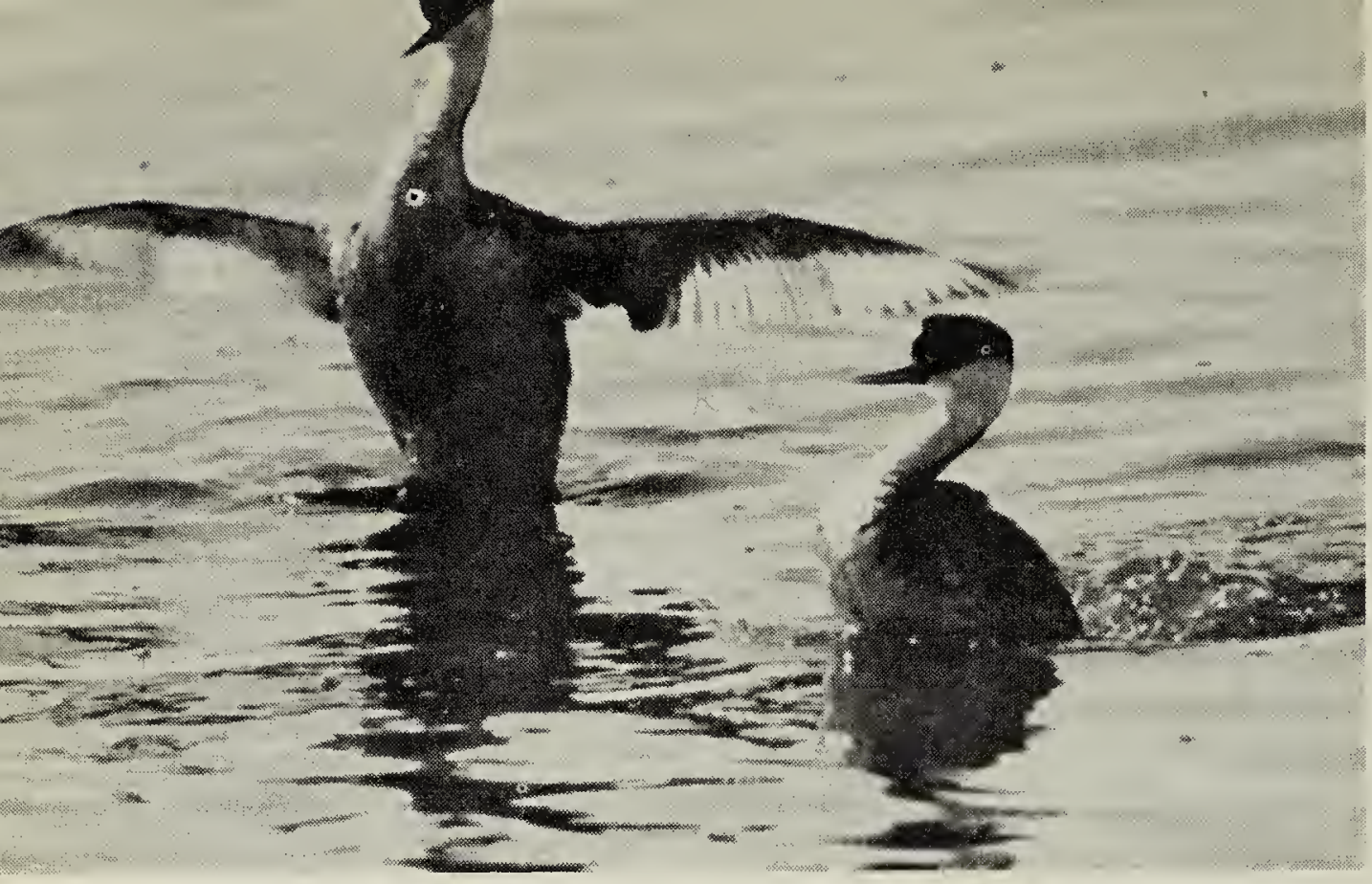

Note the relatively small wings.

Wet grebes, anxious to return to shore.
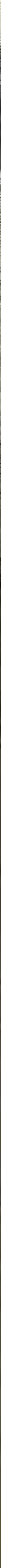

Another problembound in a rubber ring from lagoon debris. 


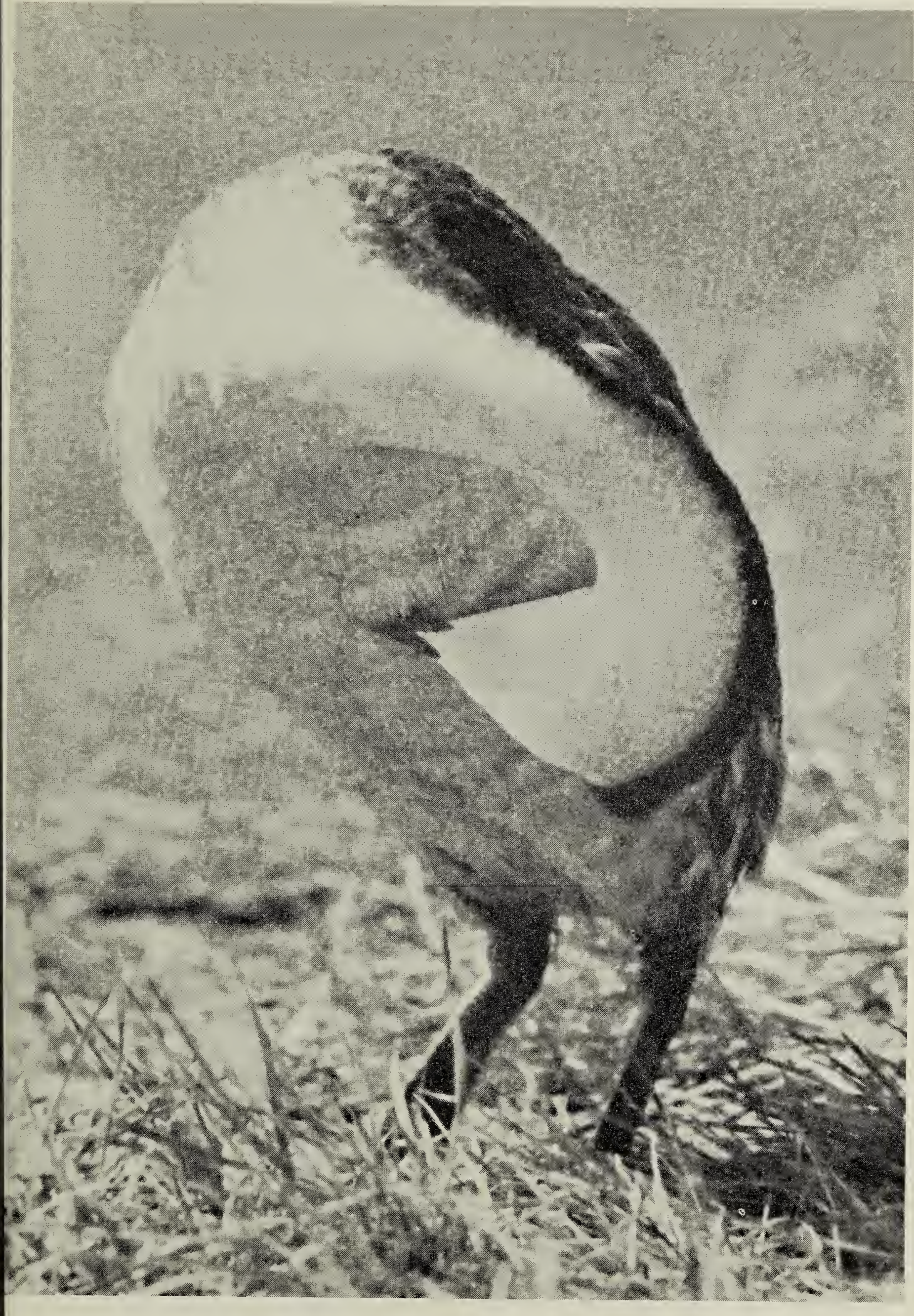

Western Grebe standing upright, squeezing water from wet belly feathers.

March, 1968 